\title{
A Variable Speed Wind Turbine Flywheel Based Coordinated Control System for Enhancing Grid Frequency Dynamics
}

\author{
Kenneth E. Okedu iD \\ Department of Electrical and Electronic Engineering, Kitami Institute of Technology, Hokkaido, Japan \\ Department of Electrical and Communication Engineering, National University of Science and Technology, Muscat, Oman \\ Department of Electrical and Electronic Engineering, Nisantasi University, Istanbul, Turkey \\ (kenokedukenneth@nu.edu.om or kenokedu@yahoo.com)
}

Received: 12.06.2018 Accepted: 29.06.2018

\begin{abstract}
The uncertain nature of wind energy is an issue in the smooth operation of grid connected wind farms. Grid operations have to satisfy the stipulated grid codes for frequency control. In this paper, grid network that is made up of steam and hydro turbines are connected to three wind farms using different control topologies. The first wind farm consist of only fixed speed induction generator wind turbines. The second wind farm is composed of only variable speed Doubly Fed Induction Generator (DFIG) wind turbines. A flywheel based DFIG system is used in the third wind farm. The reference power of the DFIG in the third wind farm is controlled in such a way as to smoothen its output during dynamics periods, while at the same time generate excess kinetic energy in the flywheel which is injected into the system to improve its performance. A comparative study was carried out on the dynamic performance of the grid network considering the same wind speed condition for the three schemes used in the wind farms. The coordinated control scheme in the third wind farm enhances the frequency response and other variables of the power system. Simulations were carried out using Power System Computer Design and Electromagnetic Transient Including DC.
\end{abstract}

Keywords Doubly fed induction generator, wind turbines, wind energy, frequency control, Stability.

\section{Introduction}

With tremendous rise in renewable energy penetration into the grid system, there is bound to be disturbance in the power network. Consequently, the grid network and its control associates are becoming complex by day. The penetration of wind power into operational power network causes frequency distortions due to the uncertain nature of wind energy. The automatic load frequency control can be used to maintain the grid system frequency by variation of the governor set points [1,2].

One of the major advantages of the use of the Doubly Fed Induction Generator (DFIG) in wind energy application is that only $20-30 \%$ of the DFIG rating is required for the power converters interfacing the rotor with the grid $[3,4]$. Apart from this, compared with the fixed speed induction generator used in wind power system, DFIG possess benefits like better wind energy capture, four quadrants active and reactive power regulation, cheap power converter system and reduced power loss, hence making the DFIG based variable wind speed turbine most popular [5].
One of the major advantages of the use of the Doubly Fed Induction Generator (DFIG) in wind energy application is that only $20-30 \%$ of the DFIG rating is required for the power converters interfacing the rotor with the grid $[3,4]$. Apart from this, compared with the fixed speed induction generator used in wind power system, DFIG possess benefits like better wind energy capture, four quadrants active and reactive power regulation, cheap power converter system and reduced power loss, hence making the DFIG based variable wind speed turbine most popular [5].

Recently, the FES is used as a common solution for enhancing frequency and power quality control of grid connected wind farms. This is because it can offer high reliability, short response time, and low cost as compared to other solutions. In the literature, [28-30] presented the use of FES in enhancing the integration of wind energy system to power networks, by using it to compensate for wind power fluctuations. Consequently, a large FES can be used to regulate the frequency of a power network. However, the cost of the FES is high because of its components like mass, generator, cooling unit, bearings, and other ancillary devices. 
Although, a small FES could be used to store fraction of energy is small quantity that is suitable for controlling wind energy variations.

It was reported in [31-34] that the Braking Resistor could be used to improve the performance of grid connected wind farms. This is because it enhances the output and limit the speed of the turbine. In [35], the concept of the braking resistor in conjunction with ECS was used in improving the stability of the frequency of a grid connected multi-machine system in a wind farm.

This paper tends to improve the performance of the frequency of a grid network using a coordinated flywheel based DFIG system. The considered model system is composed of a steam and hydro synchronous generators connected a three wind farms. Wind farm A has conventional squirrel cage induction generator wind turbines that is of fixed speed type. In wind farm B, the conventional DFIG induction generator wind turbines were considered. Wind farm $\mathrm{C}$ is composed of the proposed flywheel DFIG controller. During wind power dynamic periods, above the rated wind turbine speed, the excess kinetic energy generated is used to boast the frequency of the grid network. During periods of steady and low wind speeds, no excess kinetic energy is generated in in the flywheel system. Simulations were run using the Power System Computer Aided Design and Electromagnetic Transient Including DC (PSCAD/EMTDC) platform [36]. The study was done using three natural wind speed data obtained from Hokkaido Island, Japan, for each generator in each wind farm. The simulation was carried out for three different scenarios, where each farm is connected to the grid network at a time under same conditions and wind speeds, for effective comparative study. The presented simulation results show the improved performance of grid connected wind farm C, conventional synchronous generators and the entire grid network using the latter scheme.

\section{Model System of Study}

The model system of study is shown in Fig. 1. The wind turbines are modeled based on [33]. The power ratings of the steam and hydro synchronous generators are $30 \mathrm{MW}$ and 20MW respectively. The power ratings of each wind turbines in the wind farms are $2.5 \mathrm{MW}$ each, however, for simulation case, three aggregated wind turbines of $10 \mathrm{MW}$ capacity each were used in this study. The parameters of the wind turbines and synchronous generators are given in Table $1[33,35]$. In the model system presented in Fig. 1, three wind farms were connected to an existing grid network made up of steam and hydro turbines. Wind farm $\mathrm{A}$ is made of three conventional fixed speed induction generator wind turbines. In wind farm $\mathrm{B}$, the conventional DFIG wind turbine control strategy was used. Wind farm-3 is composed of three DFIG wind turbines with Maximum Power Point Tracking (MPPT) and flywheel based system for improved performance. Three natural wind speeds were used in the study for the three wind turbines in all the wind farms for effective comparison of the performance of the system. The parameters of the lines, transformers and loads are shown in the model system.

\section{The DFIG Flywheel System}

Figure $2 \mathrm{a}$ shows the control strategy of a conventional DFIG-based variable speed wind turbine used for wind farm B of this study. The DFIG flywheel energy system (Fig. 2b) consist basically of an induction machine of high inertia and a back to back converter system which is made up of a Rotor Side Converter (RSC) and Grid Side Converter (GSC). The operating principle is such that the rotating mass of the wind turbine can store and retrieve energy during operation. The excess kinetic energy stored by the flywheel turbine system is given by [37]:

$$
E=\frac{1}{2} J \omega^{2}
$$

Where $\omega$ is the rotational speed of the flywheel and $I$ is the moment of inertia. The stored energy available in the flywheel is given by:

$$
\Delta E=\frac{1}{2} J\left(\omega_{\max }^{2}-\omega_{\min }^{2}\right)
$$

From equation (1), $\omega_{\max }$ and $\omega_{\min }$ are the highest and lowest speeds of the flywheel system. Concerning the electrical side of the system, the stator circuit power exchange and the electrical torque of the wind generator is given as [38, 39]:

$$
\begin{gathered}
S_{s}=j \frac{3}{2}\left(\omega+\omega_{r}\right) \lambda_{s} \frac{\lambda_{s}-L_{m} i_{q d r}^{*}}{L_{s}} \\
T_{e}=\frac{3}{2} \frac{L_{m}}{L_{s}} \lambda_{s} \operatorname{Im}\left(i_{q d r}^{*}\right)
\end{gathered}
$$

From equations (3) and (4), $\omega_{r}$ is the electrical angular velocity $\left(\omega=\omega_{0}-\omega_{r}\right), \lambda_{s}$ is the stator linkage flux, $L_{m}$ is the magnetizing inductance, $L_{S}$ is the stator inductance, and $i_{q d r}^{*}$ is the conjugate of the rotor current.

Considering the Clarke and Park transformation, the rotor reference frame can be used for abc to dq conversion. The rotor current from equations (3) and (4) can be expressed in the dq frame as $[40,41]$ :

$$
i_{q d r}=i_{q r}+j i_{d r}
$$

Putting equation (5) into (3) and (4) respectively, gives:

$$
\begin{aligned}
& S_{s}=-\frac{3}{2}\left(\omega+\omega_{r}\right) \lambda_{s} \frac{L_{m} i_{d r}}{L_{s}}+j \frac{3}{2}(\omega+ \\
& \left.\omega_{r}\right) \lambda_{s} \frac{\lambda_{s}-L_{m} i_{q r}}{L_{s}}
\end{aligned}
$$




$$
T_{e}=-\frac{3}{2} \frac{L_{m}}{L_{s}} \lambda_{s} i_{d r}
$$

Thus, the active and reactive powers of the stator are the real and imaginary parts of equation (6) as shown below:

$$
\begin{aligned}
& P_{s}=-\frac{3}{2}\left(\omega+\omega_{r}\right) \lambda_{s} \frac{L_{m} i_{d r}}{L_{s}} \\
& Q_{s}=\frac{3}{2}\left(\omega+\omega_{r}\right) \lambda_{s} \frac{\lambda_{s}-L_{m} i_{q r}}{L_{s}}
\end{aligned}
$$

The electrical torque and the stator power of the DFIG wind generator can be controlled with the help of the rotor current as shown in equations (7), (8) and (9) respectively.

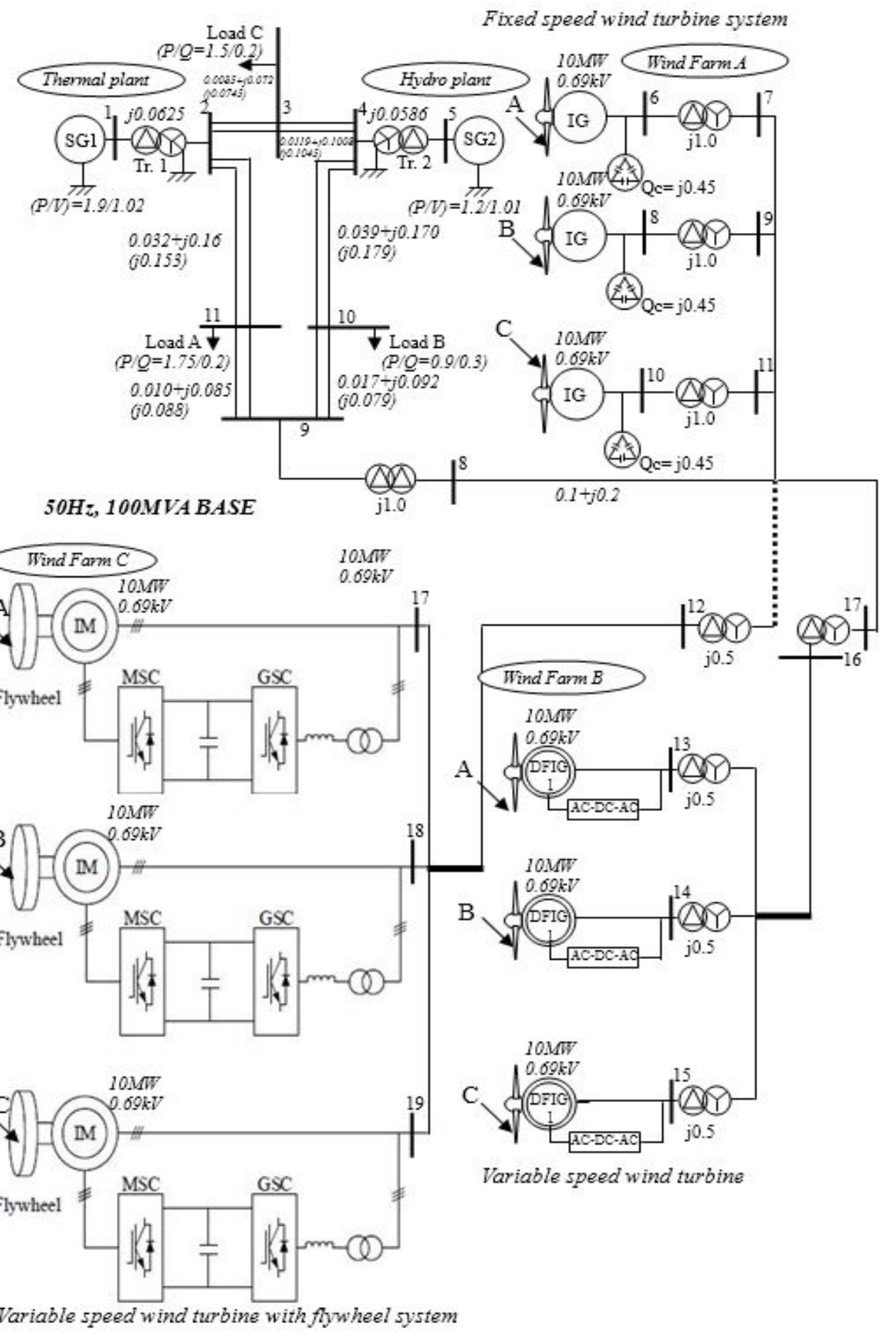

Fig.1.1 Model system 
Table 1 Generator Parameters

\begin{tabular}{|c|c|c|c|c|c|}
\hline Generator & SG1 & SG2 & Generator & IGs & DFIGs \\
Type & & & Type & & \\
\hline MVA & 30 & 20 & MVA & 15 & 15 \\
\hline $\mathrm{r}_{\mathrm{a}}(\mathrm{pu})$ & 0.003 & 0.003 & $\mathrm{r} 1(\mathrm{pu})$ & 0.01 & 0.01 \\
\hline $\mathrm{X}_{\mathrm{a}}(\mathrm{pu})$ & 0.102 & 0.130 & $\mathrm{x} 1(\mathrm{pu})$ & 0.1 & 0.15 \\
\hline $\mathrm{X}_{\mathrm{d}}(\mathrm{pu})$ & 1.651 & 1.200 & $\mathrm{Xmu}(\mathrm{pu})$ & 3.5 & 3.5 \\
\hline $\mathrm{X}_{\mathrm{q}}(\mathrm{pu})$ & 1.590 & 0.700 & $\mathrm{r} 21(\mathrm{pu})$ & 0.035 & 0.01 \\
\hline $\mathrm{X}_{\mathrm{d}}^{\prime}(\mathrm{pu})$ & 0.232 & 0.300 & $\mathrm{x} 21(\mathrm{pu})$ & 0.030 & 0.15 \\
\hline $\mathrm{X}_{\mathrm{q}}^{\prime}(\mathrm{pu})$ & 0.380 & & $\mathrm{r} 22(\mathrm{pu})$ & 0.014 & \\
\hline $\mathrm{X}_{\mathrm{d}}^{\prime \prime}(\mathrm{pu})$ & 0.171 & 0.220 & $\mathrm{x} 22(\mathrm{pu})$ & 0.098 & \\
\hline $\mathrm{X}_{\mathrm{q}}^{\prime \prime}(\mathrm{pu})$ & 0.171 & 0.250 & & & \\
\hline $\mathrm{T}^{\prime} \mathrm{do}(\mathrm{sec})$ & 5.900 & 5.000 & & & \\
\hline $\mathrm{T}^{\prime} \mathrm{qo}(\mathrm{sec})$ & 0.535 & & & & \\
\hline $\mathrm{T}^{/ /} \mathrm{do}(\mathrm{sec})$ & 0.033 & 0.040 & & & \\
\hline $\mathrm{T}^{\prime /} \mathrm{qo}(\mathrm{sec})$ & 0.078 & 0.050 & & & \\
\hline $\mathrm{H}(\mathrm{sec})$ & 3.500 & 2.500 & & & \\
\hline & & & & & \\
\hline
\end{tabular}

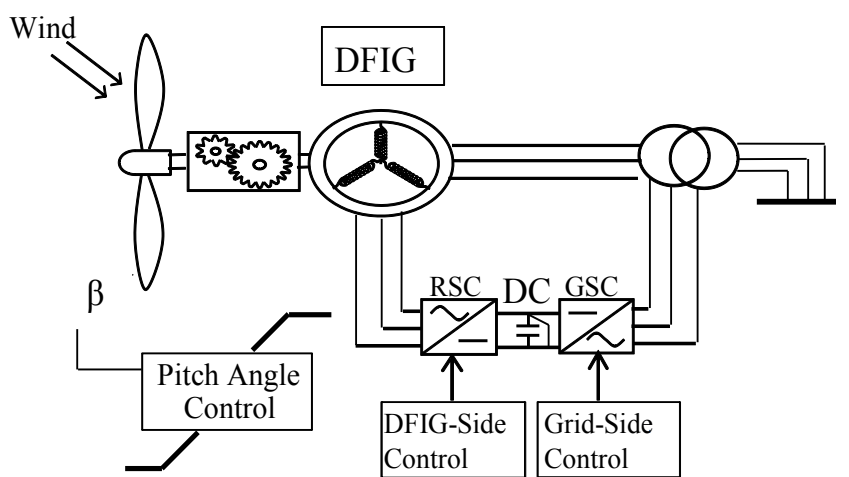

(a). Conventional DFIG control strategy (wind farm B)

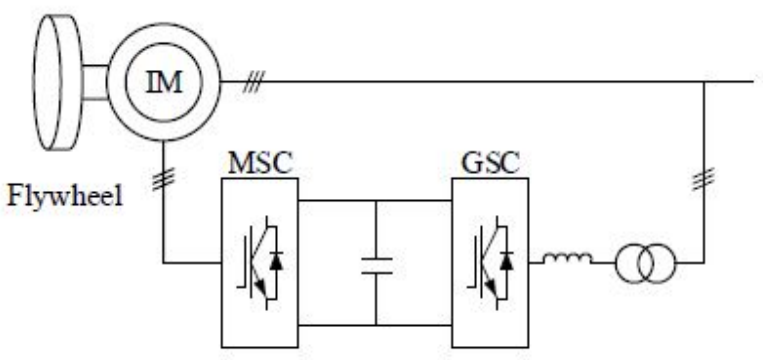

(b). Flywheel system

Fig 2. DFIG wind turbine system

\section{The Proposed DFIG Control Strategy}

The proposed DFIG control strategy for frequency control based on the flywheel energy system and coordinated 
MPPT control is shown in Fig. 3. The Phase Locked Loop (PLL) control strategy for the DFIG wind generator is shown in Fig 4.

In Figure 3, the rotor side converter of the DFIG is controlled based on the available wind speed (A, B or C) in the model system, the rotor speed $W_{1}$, the grid voltage $V_{g}$ and the grid power $\mathrm{P}_{\mathrm{g}}$ respectively. The detected real and reactive power of the grid $\left(\mathrm{P}_{1}, \mathrm{Q}_{1}\right)$ for each side of the DFIG wind generator are also used for the control of active and reactive power of the DFIG. The effective synchronization of the grid voltage is carried out with the help of the PLL, $\theta_{P L L}$ is the angle that is used for abc to $\mathrm{dq}$ and $\mathrm{dq}$ to $\mathrm{abc}$ conversion. The coordinated control of the PLL scheme for the three DFIG wind generators in wind farm $\mathrm{C}$ is shown in Fig. 5. The reference power calculation is carried out to generate a smoothed reference power to help in frequency control during periods of dynamics or disturbances in the power system due to wind speed changes as shown in Fig. 6.

The reference power is calculated based on the wind speed data from the wind turbine. The MPPT powers are obtained which are further used to calculate the reference power for each DFIG wind generators. The summation of the reference powers for the DFIGs are added to generate the smoothed reference power $\left(P_{\text {smooth }}\right)$ of the DFIG, which is- frequency $2 \mathrm{kHz}$, which is now used for the switching of the Insulated Gate Bipolar Transistors (IGBTs) in the Pulse Width Modulation (PWM) scheme of the DFIG wind turbine.

The mechanical torque and the excess kinetic energy calculations based on the natural wind speed are shown in Fig. 8. During periods of high wind speeds above the rated turbine wind speed, excess kinetic energy is developed which is stored in the flywheel and used as energy storage to improve the frequency of the grid system. From Fig. 8, the coordinated control of the pitch angle controller, mechanical torque and the excess kinetic energy developed in the system is achieved via the design values shown in the figure. The pitch controller controls the rotor speed within the rated value of $1.3 \mathrm{pu}$, based on the wind turbine characteristics. The output of the pitch angle in conjunction with the parameters of the wind speed is used in developing the mechanical torque which is transmitted via the drive train model to turn the DFIG wind generator. The excess kinetic energy developed which is in based on the wind speed, the wind generator inertia, rotor speed and power capacity of the wind turbine is shown also in Fig. 8.

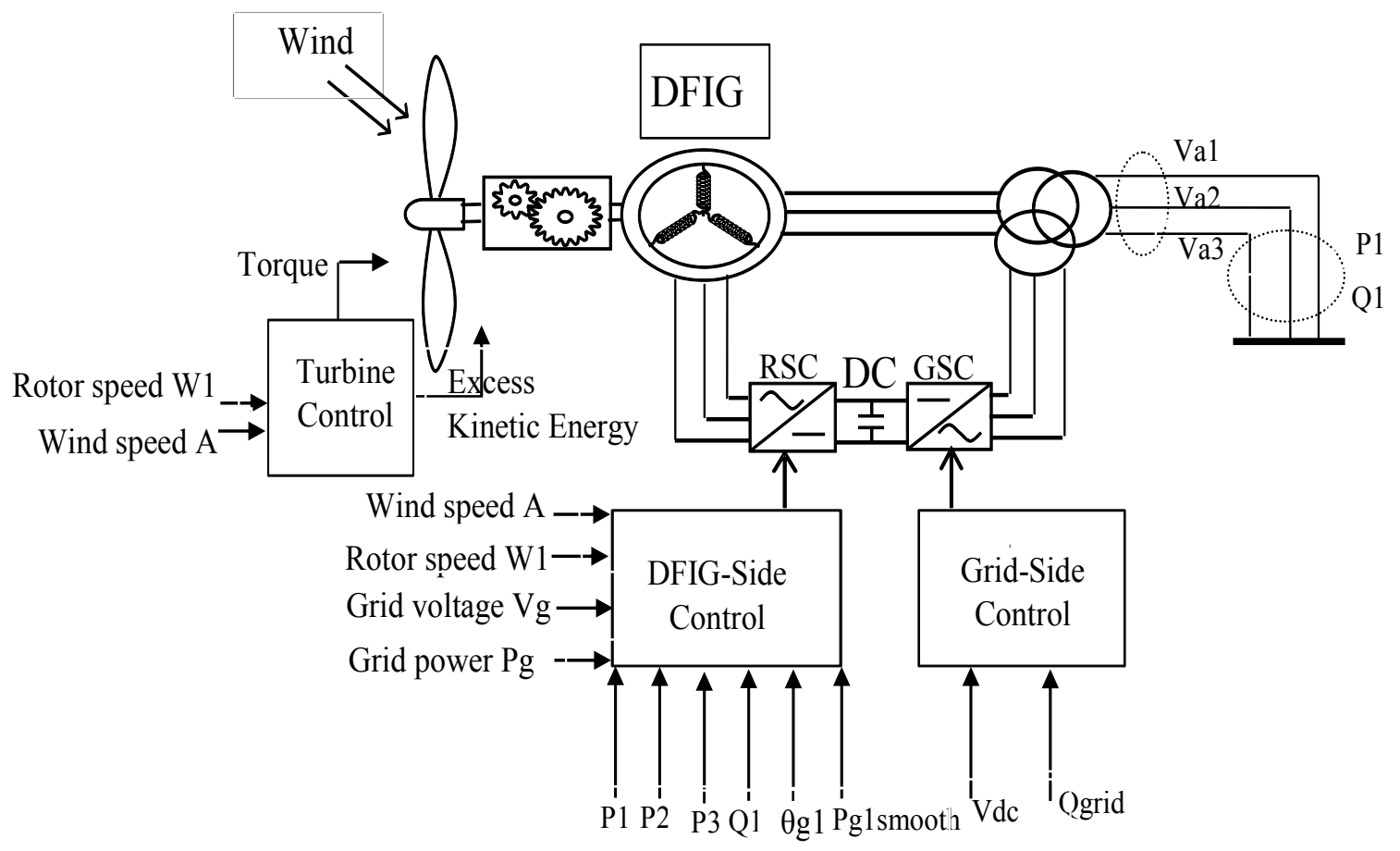

Fig 3. Proposed DFIG MPPT system in wind farm C

-used by the three DFIGs in wind farm $\mathrm{C}$ as shown in Fig. 7.

The d-axis current is used to control the q-axis reference voltage, while the q-axis current is used to control the d-axis reference voltage. After a dq to abc transformation, the reference voltage are compared with a signal generator of 


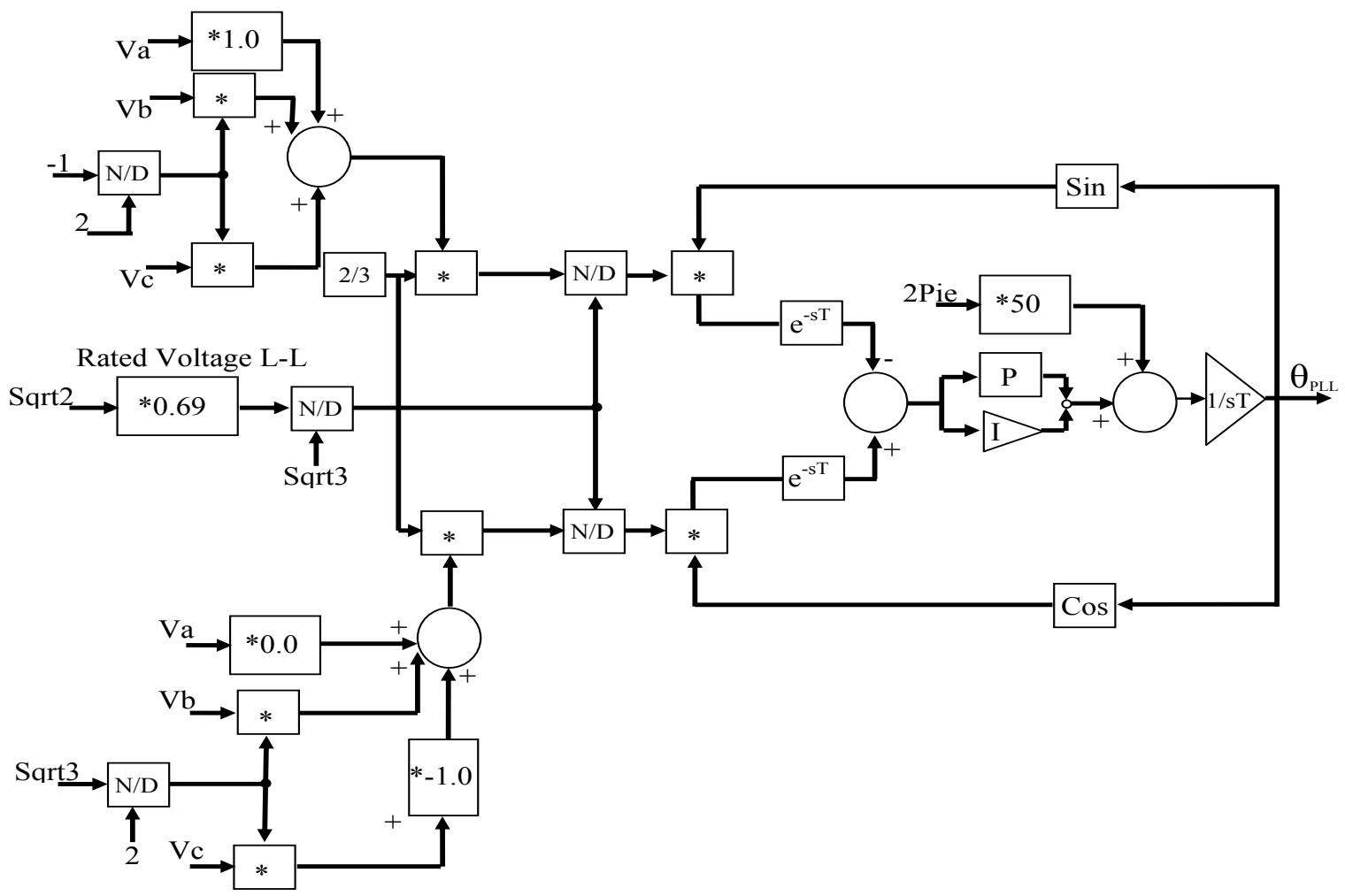

Fig 4. Control strategy of the Phase Lock Loop (PLL) in wind farm C

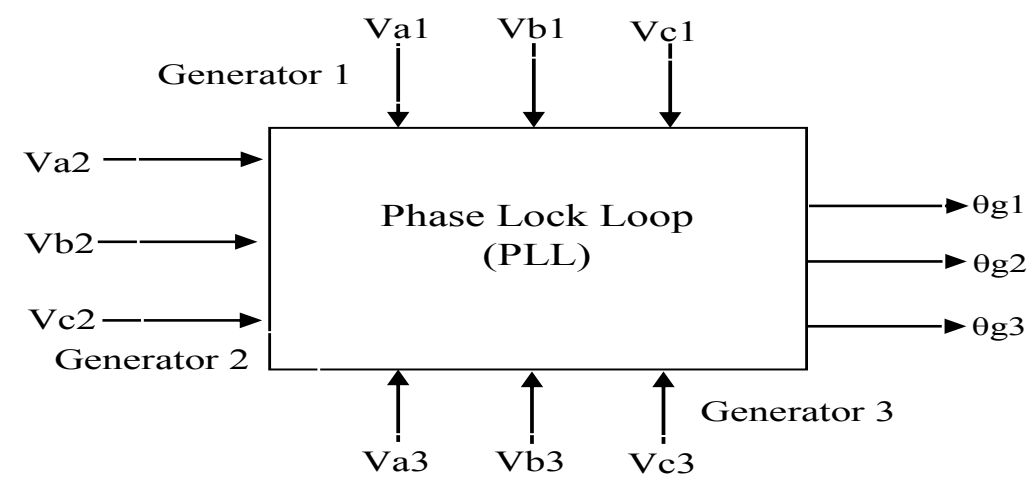

Fig 5. Coordinated phase lock loop system for the DFIG wind generators in wind farm C

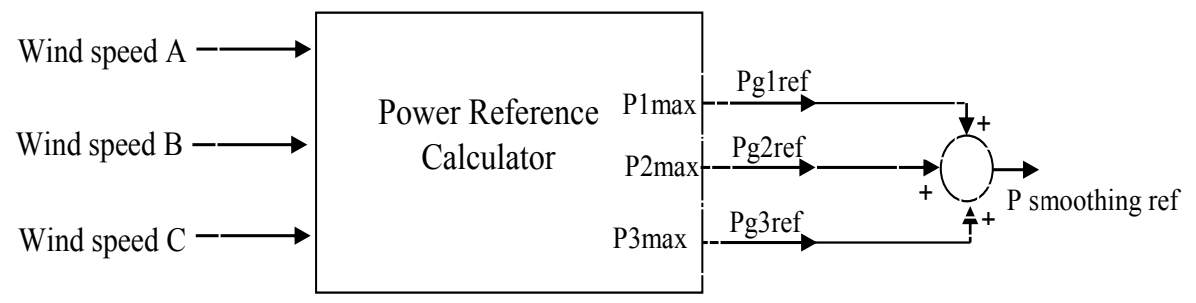

Fig 6. Three DFIGs reference power calculation in wind farm $\mathrm{C}$ 


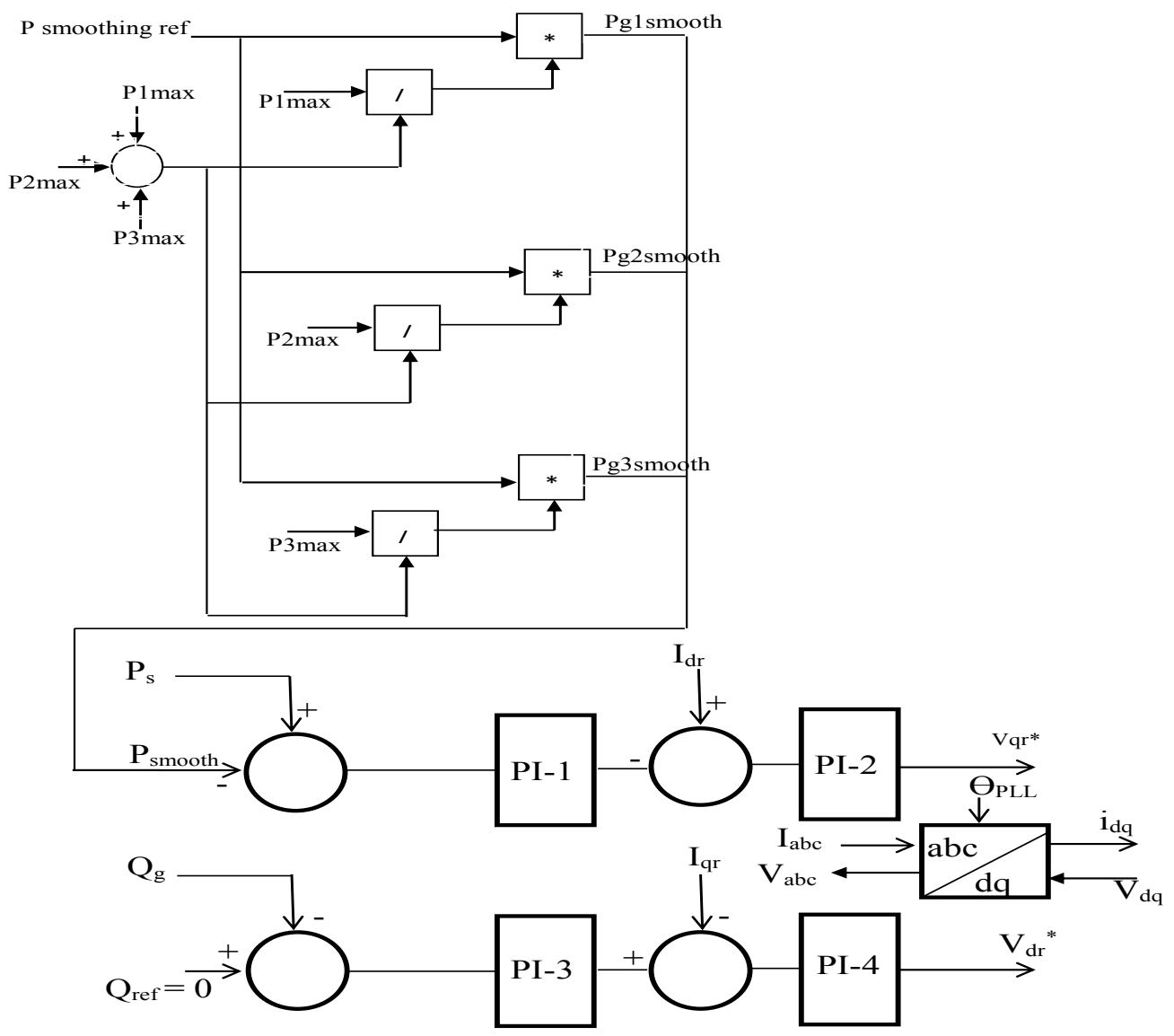

Fig 7. DFIG smoothed reference power in wind farm C

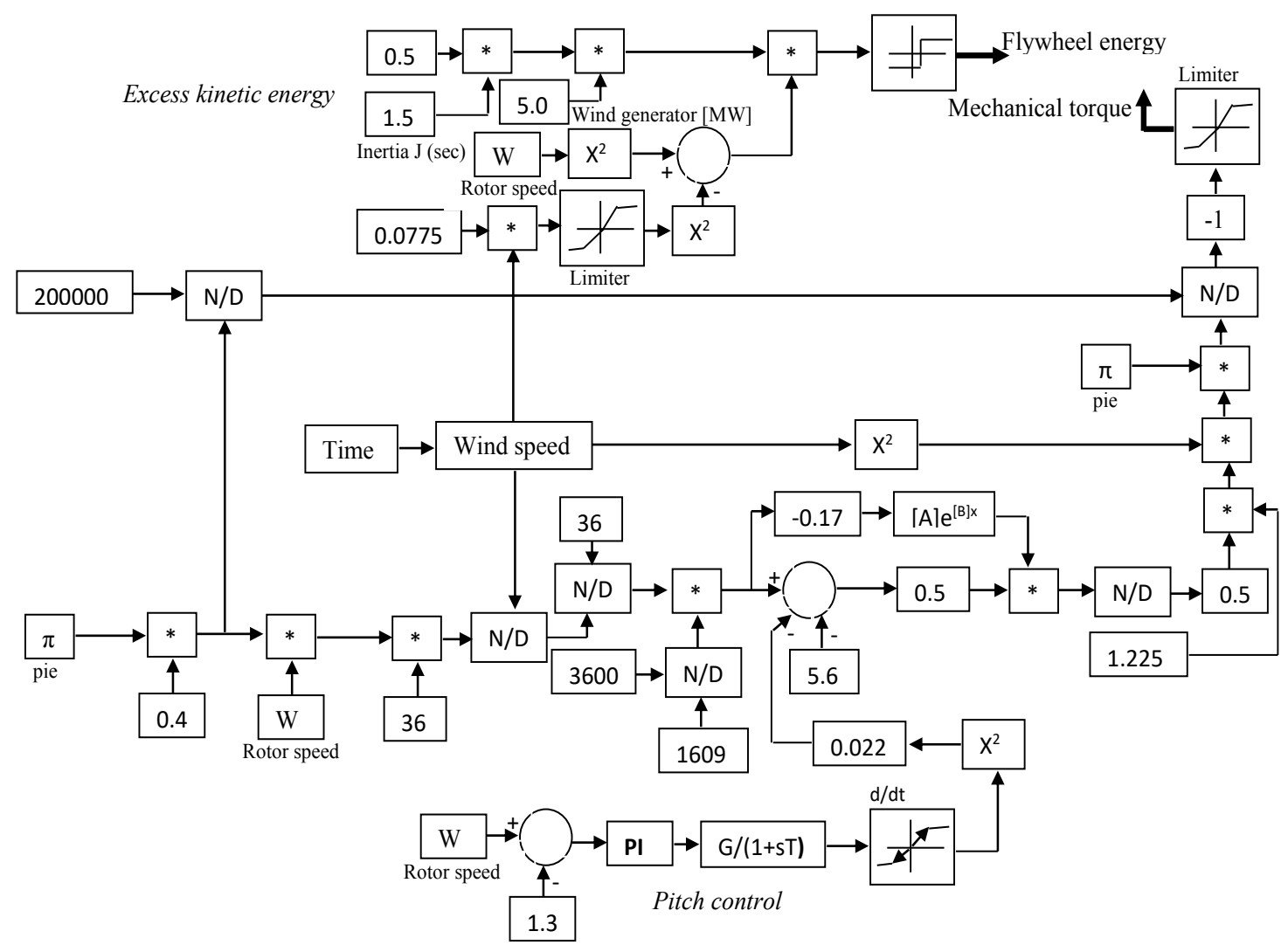

Fig 8. Coordinated control of the pitch control and excess kinetic energy 


\section{Simulation Results and Discussions}

Simulation was carried out considering the model system presented in Fig. 1, using wind speed data (Fig. 9) obtained from Hokkaido Island in Japan. The simulation was run for 600 seconds in PSCAD/EMTDC platform, to demonstrate the rigidity of the controllers employed in the system. The same wind speed data were used for the three wind farms for effective comparative study. The wind farms were connected one at a time to the existing grid.

From Fig. 10, the frequency distortion during dynamics was much considering the use of the fixed speed induction generator wind turbines in wind farm $\mathrm{A}$ and the conventional control strategy for DFIG wind turbines in wind farm B. This is because these wind turbines lack the capability to control the frequency of the system. Consequently, the grid frequency reaches about $47 \mathrm{pu}$ during the grid dynamics, which would lead to the shutdown of the wind farm based on the stipulated grid requirement of minimum value of $49 \mathrm{~Hz}$. The use of the proposed coordinated control for the DFIG wind turbines in wind farm $\mathrm{C}$ in Fig. 10 shows improved performance of the grid frequency during the grid dynamics, in order to suit the grid codes which requires a minimum of $49 \mathrm{~Hz}$ frequency dip. The excess kinetic energy developed by the DFIG wind turbines flywheel system based on the control strategy in Fig. 8, is shown in Fig. 11. From Fig. 11, more kinetic energy was generated for energy storage in DFIG-2 because of the nature of the wind speed for speed $\mathrm{B}$ as shown in Fig. 9. DFIG-3 in wind farm $\mathrm{C}$ has less developed kinetic energy during the system dynamics based on wind speed $\mathrm{C}$. This is due to the fact that wind speed $\mathrm{B}$ is higher above the rated DFIG wind generator wind speed, between 0 to 150 seconds, and lower than the rated DFIG wind generator wind speed, between 150 seconds to 300 seconds. In this period, zero kinetic energy is developed, for energy storage, while from 300 seconds to 600 seconds, more kinetic energy was developed again, thus, showing the effectiveness of the controllers during grid dynamics.
The responses of the synchronous generators in the wind farms are presented in Figs. 12 and 13 respectively, where more distortions in the variables of the synchronous plants were obtained in wind farms $\mathrm{A}$ and $\mathrm{B}$, where no control strategy was implemented.

The rotor speeds of the DFIG wind generators are shown in Fig. 14 for wind farm-C. Based on the control strategy implemented in Fig. 8 for the pitch control of the DFIG system and the turbine characteristics used for this study, the rotor speed is operated within $0.7 \mathrm{pu}$ for minimum speeds and $1.3 \mathrm{pu}$ for maximum speeds, considering the nature of the wind speeds displayed in Fig. 9.

\section{Conclusion}

It is imperative to mitigate the fluctuations in grid connected wind farms considering recent grid codes for optimum and effective operation of power networks made up of multi-machine systems. The performance of a variable speed wind turbine that is DFIG based considering a coordinated control of the maximum power point tracking and a flywheel system to smoothen the reference power of the wind turbine during dynamics has been presented in this paper. The control strategy makes the use of excess kinetic energy that is generated in the flywheel system based on the nature of available wind speeds. The proposed control strategy of the DFIG for frequency control was further compared to other configurations of wind farm considering no control strategy. The responses of the grid frequency, power network and other variables of the grid connected wind farm, show improved performance during periods of grid dynamics.

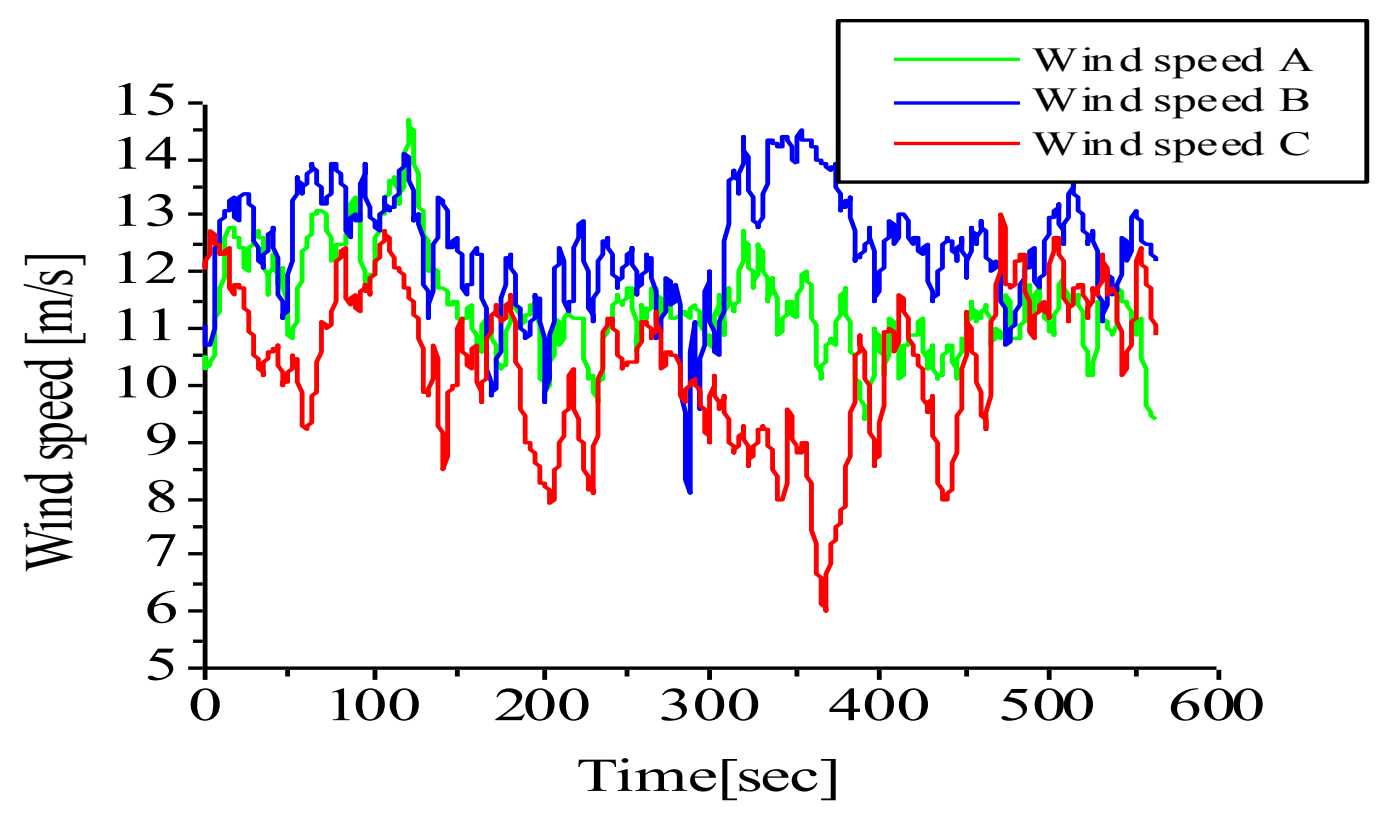

Fig 9. Wind speed 


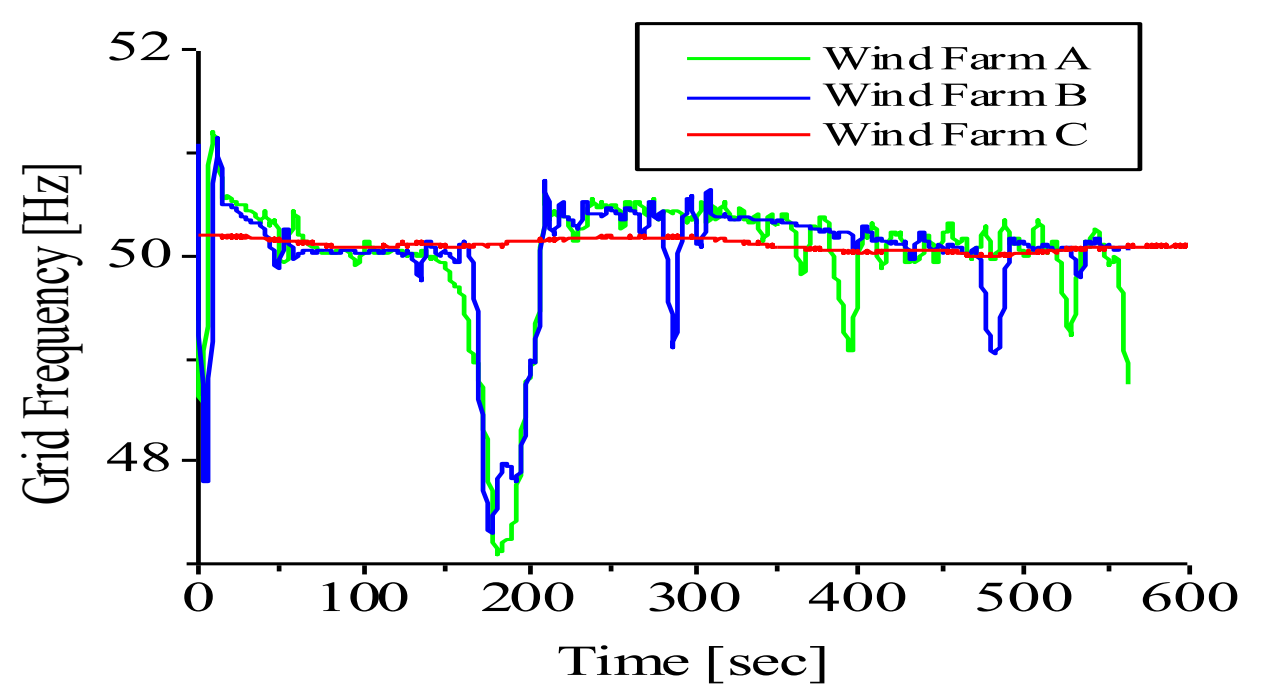

Fig 10. Grid frequency

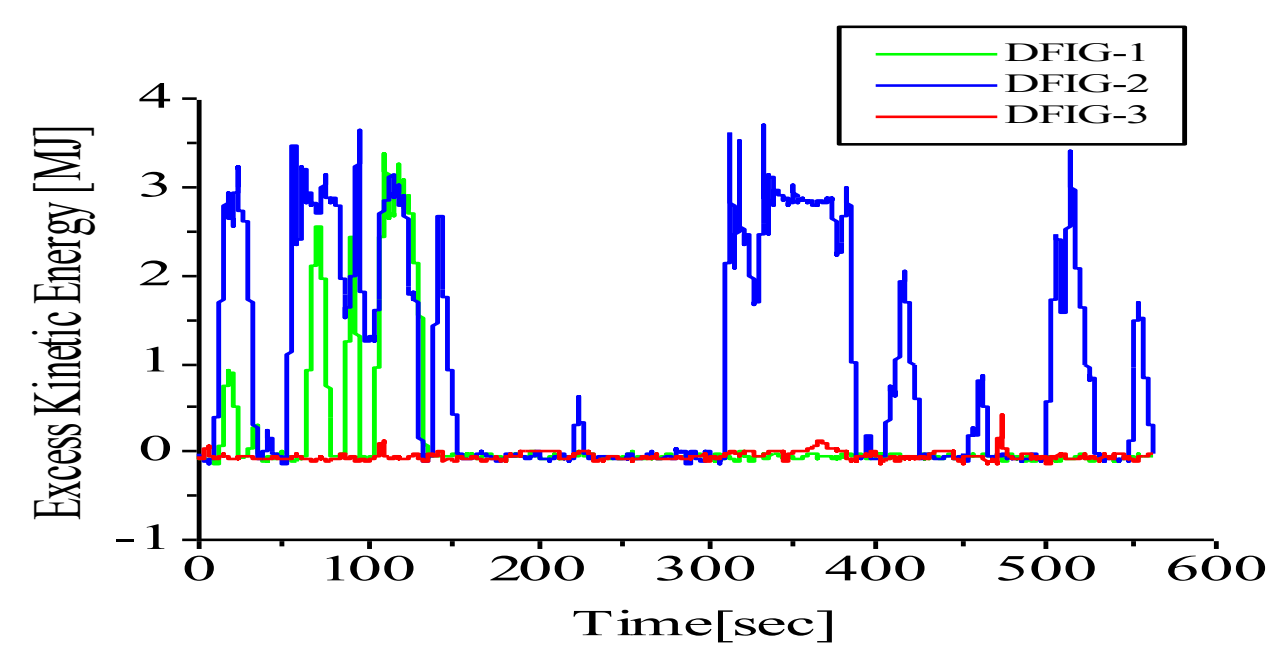

Fig 11. Excess kinetic energy (wind farm C)

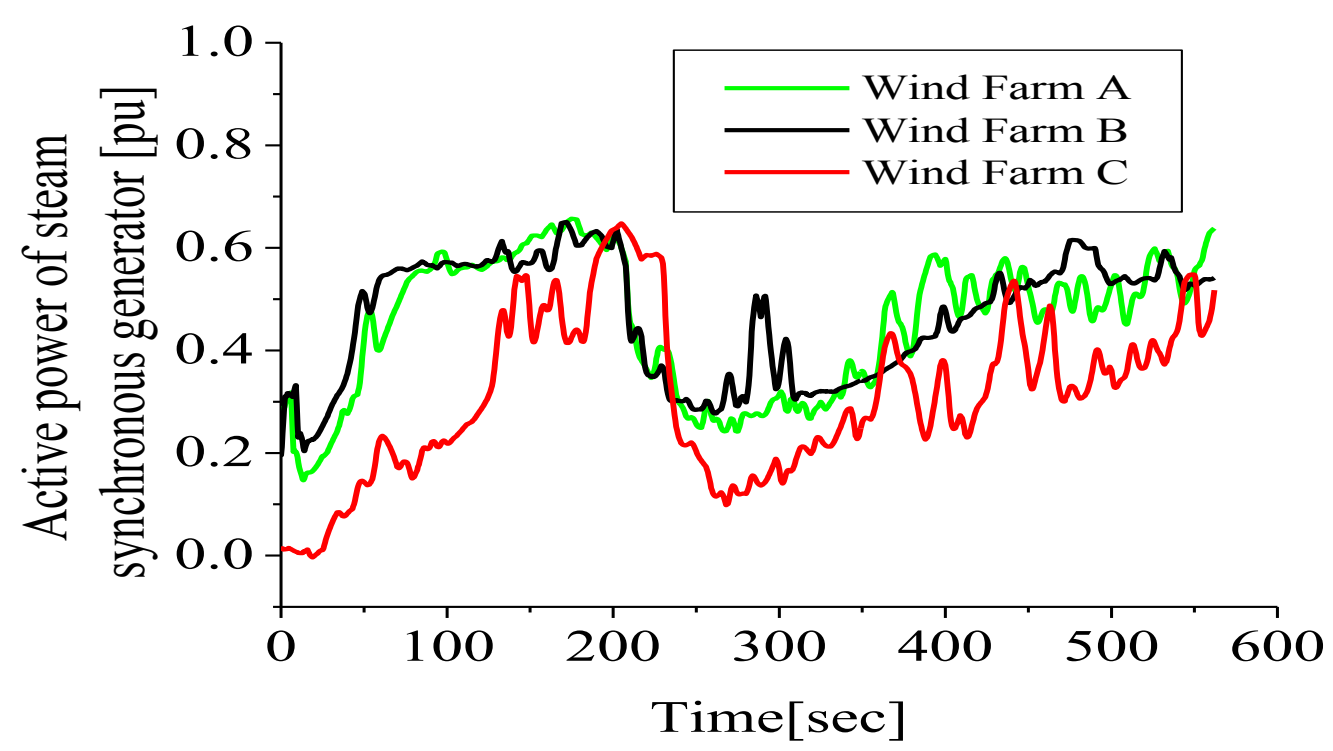

Fig 12. Active power of steam synchronous generators 


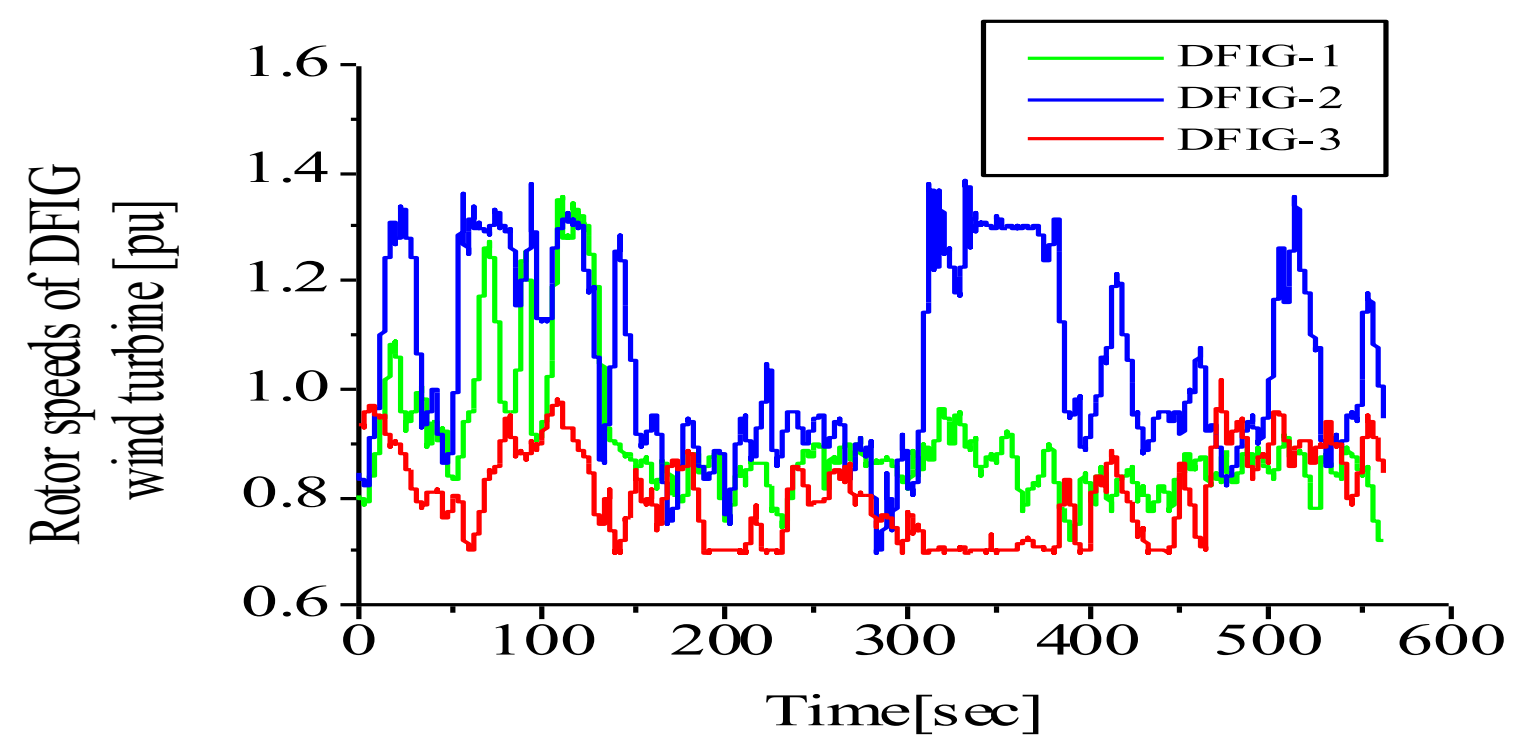

Fig 13. Active power of hydo synchronous generators

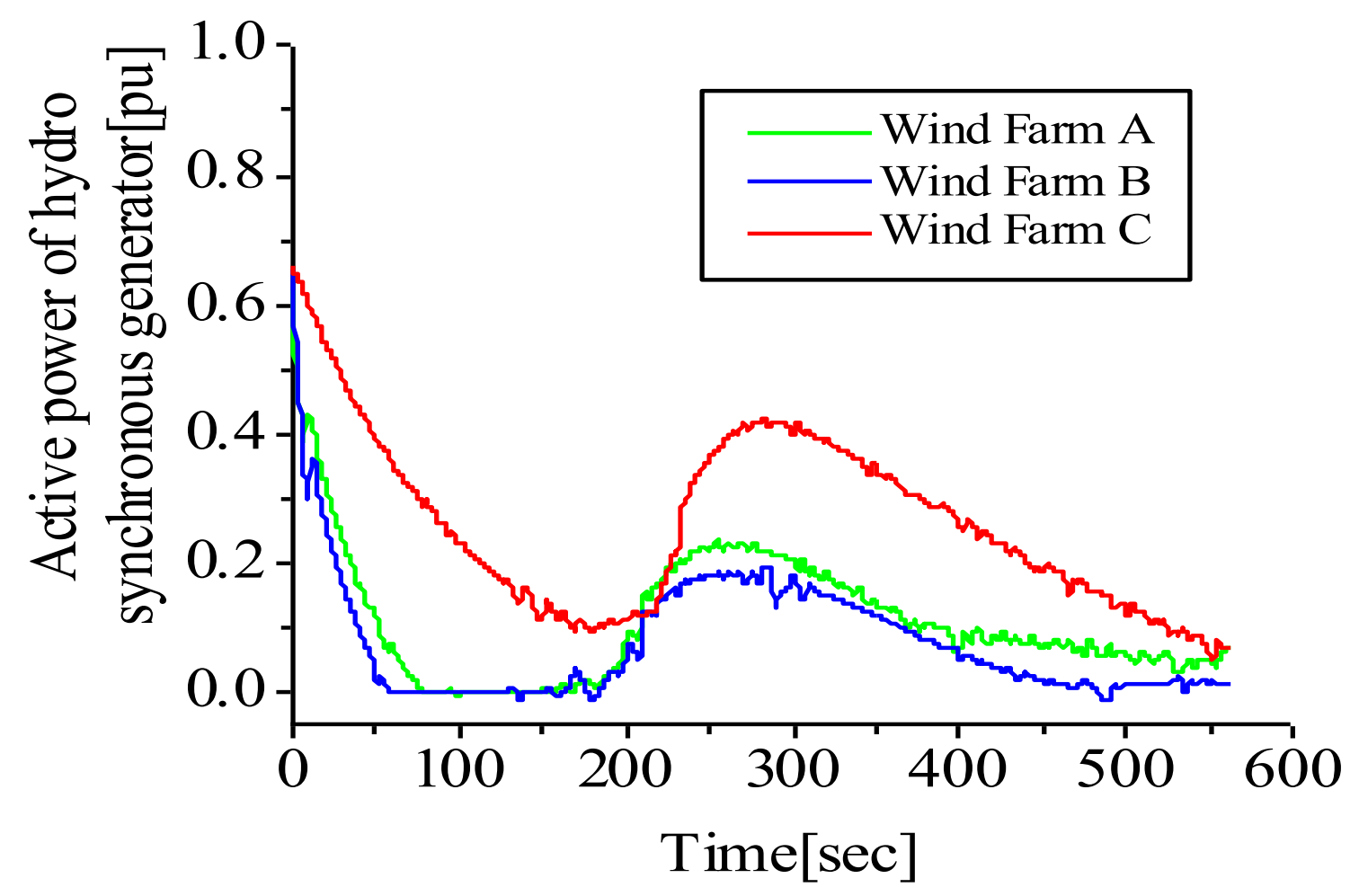

Fig 14. Rotor speeds of DFIG wind generators in wind farm C 


\section{References}

[1] S. Ramesh and A. Krishnan, "Stabilization of frequency deviation in an AC-DC interconnected power systems using supervisory fuzzy controller", Tamkang Journal of Science and Engineering, vol. 14, no. 4, pp. 341-349, 2011.

[2] G. Gross and J. W. Lee, "Analysis of load frequency control performance assessment criteria", IEEE Transactions on Power Systems, Vol. 16, pp. 520-525, 2001.

[3] K.E. Okedu, S. M. Muyeen, Rion Takahashi and Junji Tamura, "Protection schemes for DFIG considering rotor current and DC-link voltage", 24th IEEE-ICEMS (International Conference on Electrical Machines and System), Beijing, China, pp. 1-6, August 2011.

[4] D. Hulst, M. Fernadez, et al "Voltage and frequency control for future power systems: the Electra IRP Proposal", Proceedings International symposium in smart electric distribution systems and technologies, pp. 245-250, 2015.

[5] Wu, B.; Lang, Y.; Zargari, N.; Kouro, S. Power Conversion and Control of Wind Energy Systems, 1st ed.; Wiley-IEEE Press: Hoboken, NJ, USA, 2011; pp. 153-170.

[6] K. Jagathessan, and N. 'Artificial intelligence in performance analysis of load frequency control in thermal wind hydropower system', International Journal of Advanced Computer Science and Applications, 2015, 6, (7), pp. 203-212.

[7] T. Messikh, S. Mekhilef, and N. A. Rahim, "Adaptive notch filter for harmonic current mitigation", World Academy of Science Engineering and Technology, 2008, 22, pp. 907-913.

[8] K. Saiteja, and M. S. Krishnarayalu, "Load frequency control of two area smart grid," International journal of computer applications, 2015, 117, pp. 1-9.

[9] F. Wilches-Bernal, and J. H. Chow, "A fundamental study of applying wind turbines for power system frequency control", CFES annual conference, 2015.

[10]K. P. Singh, "Load frequency control of multi-source power system with redox flow batteries: An analysis", International Journal of Computer Applications, vol. 88, no. 8, pp. 46-52, 2014.

[11]I. Kumar, and D. P. Kothari, "Recent philosophies of automatic generation control strategies in power systems", IEEE Transactions Power System,vol. 20, no. 1, pp. 346-357, 2005.

[12] S. Adhikari, F. Li, “Coordinated V-f and P-Q Control of Solar Photovoltaic Generators with MPPT and Battery Storage in Micro grids", IEEE Trans. Smart Grid, vol. 5, pp. 1270-1281, 2014.

[13] I. Serban, C. Marinescu, "Control strategy of three-phase battery energy storage systems for frequency support in micro grids and with uninterrupted supply of local loads", IEEE Trans. Power Electron., vol. 29, pp. 5010 5020, 2014.

[14] M. G. Molina, P.E. Mercado, Power flow stabilization and control of microgrid with wind generation by superconducting magnetic energy storage", IEEE Trans. Power Electron. vol. 26, pp. 910-922, 2011.

[15]I. Ngamroo, T. Karaipoom, "Improving low-voltage ride-through performance and alleviating power fluctuation of DFIG wind turbine in DC microgrid by optimal SMES with fault current limiting function", IEEE Trans. Appl. Supercond. Vol, 14, pp. x-x, 2014, doi:10.1109/TASC.2014.2333031.

[16] W. Gu, W. Liu, Z. Wu, B. Zhao, W. Chen, “Cooperative control to enhance the frequency stability of Islanded Microgrids with DFIG-SMES", Energies, vol. 6, pp. 3951-3971, 2013.

[17]F. A. Inthamoussou, J. Pegueroles-Queralt, F.D. Bianchi, "Control of a super-capacitor energy storage system for microgrid applications", IEEE Trans. Energy Convers. Vol. 28, pp. 690-697, 2013.

[18] A. Ghazanfari, M. Hamzeh, H. Mokhtari, H. Karimi, "Active power management of multihybrid fuel cell/supercapacitor power conversion system in a medium voltage microgrid”, IEEE Trans. Smart Grid, vol. 3, pp. 1903-1910, 2012.

[19]F. Islam, A. Al-Durra, S.M. Muyeen, "Smoothing of wind farm output by prediction and supervisory-controlunit-based FESS", IEEE Trans. Sustain. Energy, vol. 4, 925-933, 2013.

[20] G. O. Suvire, M. G. Molina, P. E. Mercado, "Improving the integration of wind power generation into $\mathrm{AC}$ microgrids using flywheel energy storage. IEEE Trans. Smart Grid, vol. 3, pp. 1945-1954, 2012.

[21]R. Sebastián, R. Peña Alzola, "Flywheel energy storage systems: review and simulation for an isolated wind power system", Renew. Sustain. Energy Rev., vol. 16, pp. 6803-6813, 2012.

[22]E. K. Hussain, D. Benchebra, K. Atallah, H. S. Ooi, M. Burke, and A. Goodwin, "A flywheel energy storage system for an Isolated micro-grid", In Proceedings of the Renewable Power Generation Conference, Naples, Italy, 24-25 September 2014; pp. 1-6.

[23] G. Cimuca, S. Breban, M.M. Radulescu, C. Saudemont, B. Robyns, "Design and control strategies of an induction-machine-based flywheel energy storage system associated to a variable-speed wind generator", IEEE Trans. Energy Convers. Vol. 25, pp. 526-534, 2010.

[24]L. Jerbi, L. Krichen, A. Ouali, "A fuzzy logic supervisor for active and reactive power control of a variable speed wind energy conversion system associated to a flywheel storage system", Electr. Power Syst. Res., vol. 79, pp. 919-925, 2009. 
[25]G. O. Cimuca, C. Saudemont, B. Robyns, M. M. Radulescu, "Control and performance evaluation of a flywheel energy-storage system associated to a variablespeed wind generator", IEEE Trans. Ind. Electron. vol 53, pp. 1074-1085, 2006.

[26] R. Cardenas, R. Pena, G.M. Asher, J. Clare, R. BlascoGimenez, "Control strategies for power smoothing using a flywheel driven by a sensorless vector-controlled induction machine operating in a wide speed range", IEEE Trans. Ind. Electron. vol. 51, pp. 603-614, 2004.

[27] X. Chang, Y. Li, W. Zhang, N. Wang, W. Xue, “Active disturbance rejection control for a flywheel energy storage system", IEEE Trans. Ind. Electron. vol. 62, pp. 991-1001, 2015.

[28] Y. Zhang, X. Liu and B. Qu, "Distributed model predictive load frequency control of multi-area power system with DFIGs," in IEEE/CAA Journal of Automatica Sinica, vol. 4, no. 1, pp. 125-135, Jan. 2017.

[29]Toshiba World's First Successful Commercial Operation of Double-Fed Adjustable-Speed Flywheel Generating System, 1997. Available online: https://www.toshiba.co.jp/tech/review/1997/high97/pow er/p3/index.htm (accessed on 21 January 2015).

[30]L. Wang, J. Yu, Y.T Chen, "Dynamic stability improvement of an integrated offshore wind and marinecurrent farm using a flywheel energy-storage system", Renew. Power Génér., vol 5, pp, 387-396, 2011.

[31] A. Causebrook, D.J. Atkinson, and A. G. Jack, "Fault ride through of large wind farms using series dynamic braking resistors", IEEE Trans. Power Systems, vol. 22, no. 3, pp. 966-975, 2007.

[32] J. Yang, E. Fletcher, and J. O'Reilly, “A series dynamic resistor based converter protection schemes for doubly fed induction generator during various fault conditions," IEEE Tran. Energy Convers. Vol. 25, no. 2, pp. 422432, 2010.

[33] K. E. Okedu, S. M. Muyeen, R. Takahashi, and J. Tamura, "Wind farms fault ride through using DFIG with new protection scheme", IEEE Transactions on Sustainable Energy, vol. 3, no. 2, pp. 242-254, 2012.

[34]K. E. Okedu, S. M. Muyeen, R. Takahashi, and J. Tamura, "Improvement of fault ride through capability of wind farm using DFIG considering SDBR", 14th European Conference of Power Electronics EPE, Birmingham, United Kingdom, pp. 1-10, August, 2011.

[35]K. E. Okedu, "Effect of ECS low pass filter timing on grid frequency dynamics of a power network considering wind energy penetration", IET Renewable Power Generation, vol. 11, no. 9, pp. 1194-1199, 2017, DOI: $10.1049 /$ iet-rpg.2016.0855.
[36] "PSCAD/EMTDC Manual”, Manitoba HVDC research center, 1994.

[37] G. Genta, Application of flywheel energy storage system in kinetic energy storage: theory and practice of advanced flywheel systems; Butterworth: London, UK, pp. 27-46, 1985.

[38]A. Yazdani, R. Iravani, Voltage-sourced converters in power systems: modeling, control and applications, $1 \mathrm{st}$ ed.; Wiley-IEEE Press: Hoboken, NJ, USA, 2010; pp. 204-245.

[39] N. Thai-Thanh, Y. Hyeong-Jun and K. Hak-Man, “A flywheel energy storage system based on a doubly fed induction machine and battery for microgrid control", Energies, vol.8, pp. 5074-5089, 2015.

[40]P. Krause, O. Wasynczuk, S. Sudhoff, D. Pekarek, Analysis of electric machinery and drive systems, 3rd ed.; Wiley-IEEE Press: Hoboken, NJ, USA, 2013; pp. 215-267.

[41]K. E. Okedu, "Hydrogen production using variable and fixed speed wind farm topologies in a utility grid" Journal of Renewable and Sustainable Energy (JRSE), American Institute of Physics (AIP), vol. 8, no. 6, pp. 113, December, 2016, DOI: 10.1063/1.4972886 